\title{
Penentuan Tipologi Desa Wisata berdasarkan Kesamaan Karakteristik Komponen Pembentuk Desa Wisata di Kabupaten Ponorogo
}

\author{
Mada Kharisma Parasari dan Ema Umilia \\ Departemen Perencanaan Wilayah dan Kota, Fakultas Arsitektur, Desain dan Perencanaan, \\ Institut Teknologi Sepuluh Nopember (ITS) \\ e-mail: ema_umilia@urplan.its.ac.id
}

\begin{abstract}
Abstrak-Mengembangkan pariwisata di daerah perdesaan bukanlah hal yang mudah, terlebih jika langsung dalam jumlah yang besar. 70 desa telah ditetapkan sebagai lokasi pengembangan desa wisata di Kabupaten Ponorogo. Dengan kondisi Kabupaten Ponorogo yang memiliki potensi daya tarik wisata beragam dan segala keterbatasan dalam pengembangannya, maka dirasa penting untuk dilakukan suatu kajian tentang pemetaan tipologi desa wisata Kabupaten Ponorogo berdasarkan kesamaan karakteristik komponen pembentuk desa wisata. Untuk mencapai tujuan penelitian yaitu perumusan tipologi desa wisata Kabupaten Ponorogo, dilakukan 3 tahap analaisis, yaitu pertama identifikasi karakteristik komponen pembentuk desa wisata Kabupaten Ponorogo menggunakan metode analisis diskriptif; kedua, analisis variabel dalam penentuan tipologi desa wisata dengan menggunakan metode analisis Delphi; ketiga, penentuan tipologi desa wisata Kabupaten Ponorogo berdasarkan kesamaan karakteristik komponen pembentuk desa wisata dengan menggunakan metode Analitycal Hierarchy Process (AHP) dan Skoring. Dari hasil penelitian dapat diketahui bahwa desa wisata di Kabupaten Ponorogo dapat dikelompokkan menjadi 3 tipologi, yaitu Tipologi I adalah kelompok desa yang berpotensi tinggi untuk dikembangkan sebagai lokasi desa wisata, berjumlah 24 desa; tipologi II adalah desa dengan potensi sedang atau cukup, berjumlah 33 desa dan tipologi III adalah desa dengan potensi rendah untuk dikembangkan menjadi desa wisata, berjumlah 27 desa.
\end{abstract}

Kata Kunci - Desa Wisata, Tipologi, Kabupaten Ponorogo.

\section{PENDAHULUAN}

$\mathrm{P}$ ARIWISATA menjadi sektor ekonomi yang sedang gencar dikembangkan daerah-daerah di Indonesia. Nilai pertumbuhan sektor pariwisata Indonesia bahkan sempat mencapai $9,39 \%$ di tahun 2014, mengalahkan nilai pertumbuhan ekonomi yang hanya $5,04 \%$, yang artinya sektor pariwisata ini tumbuh pesat di Indonesia [1]. Beberapa tahun terakhir, perkembangan pariwisata cenderung mulai memasuki tatanan baru dengan mengusung konsep desa wisata [2]. Terbukti berdasarkan data dari Kementerian Pariwisata Republik Indonesia tahun 2014, sampai dengan tahun 2013 tercatat ada 980 desa wisata yang telah dikembangkan di Indonesia dalam program PNPM Mandiri Pariwisata. Jumlah ini meningkat tajam jika dibanding dengan tahun 2009 yang hanya tercatat 104 desa yang dikembangkan dengan tujuan pariwisata.

Seperti halnya kabupaten/kota lain di Indonesia, Kabupaten Ponorogo memiliki potensi daya tarik wisata yang cukup besar baik wisata alam, wisata budaya, wisata religi dan wisata buatan. Melihat adanya potensi tersebut, dalam Musrenbang 2016 yang membahas Rencana Pembangunan Jangka Menengah Daerah (RPJMD) Kabupaten Ponorogo tahun 2016-2021, disepakati bahwa pada tahun 2019 Pemerintah Kabupaten Ponorogo akan memfokuskan pembangunan daerah dibidang pariwisata berbasis alam, budaya, agama, dan agroindustri yang didukung infrastruktur yang kuat [3]. Dengan dikeluarkannya Peraturan Bupati Nomor 48 Tahun 2017 tentang Pedoman Penetapan Desa Wisata, yang ditindaklanjuti dengan Keputusan Bupati Nomor 188.45/1769/405.29/2017 tentang Penetapan Desa Wisata, sebanyak 70 desa di Kabupaten Ponorogo akhirnya ditetapkan sebagai lokasi pengembangan desa wisata dan jumlah ini dapat terus berubah.

Tidak hanya diberi payung hukum dalam pengembangan desa wisata, berupa MOU pemerintah dengan perhutani; desa wisata Kabupaten Ponorogo juga diberi pendampingan dan pelatihan Pokdarwis selaku pengelola desa wisata [4]. Tidak lupa, untuk memaksimalkan pengembangan pembangunan desa wisata, pemerintah menganggarkan dana sejumlah 500 juta setiap tahunnya untuk dibagikan pada 20 desa terpilih sebagai stimulan untuk mempercepat pembangunan desa sebagai desa wisata yang sesungguhnya, tepatnya dalam hal penyediaan sarana pendukung wisata. Melihat besarnya manfaat yang bisa didapatkan dari pengembangan desa wisata menjadikan banyak dari desa lain dia Kabupaten Ponorogo, diluar 70 desa yang ditetapkan, berusaha mengembangakan pariwisata desa untuk bisa mendapatkan legalitas pemerintah dengan rekomendasi dari dinas pariwisata.

Berdasarkan pemaparan diatas, banyaknya jumlah desa yang akan dikembangkan dengan beragam potensi yang dimiliki, serta keterbatasan pemerintah dalam menganggarkan dana pengembangan desa wisata menjadi dasar pentingnya untuk mengkaji tipologi pengembangan desa wisata Kabupaten Ponorogo sesuai dengan karakteristik 
yang dimiliki oleh desanya. Sehingga dalam pengembangan desa-desa wisata tersebut kedepan bisa lebih optimal, karena telah sesuai dengan potensinya.

Tabel 1

Metode Analisis

\begin{tabular}{|c|c|c|c|}
\hline & Metode & Tujuan Analisis & Hasil \\
\hline 1 & Analisis & Untuk mengetahui kondisi & Identifikasi \\
\hline & Deskriptif & $\begin{array}{l}\text { komponen desa wisata } \\
\text { yang terdapat pada setiap } \\
\text { desa wisata di Kabupaten } \\
\text { Ponorogo. }\end{array}$ & $\begin{array}{l}\text { karakteristik desa- } \\
\text { desa wisata } \\
\text { Kabupaten } \\
\text { Ponorogo. }\end{array}$ \\
\hline 2 & $\begin{array}{c}\text { Analisis } \\
\text { Delphi }\end{array}$ & $\begin{array}{l}\text { Untuk menemukan } \\
\text { variabel-variabel logis } \\
\text { yang dapat digunakan } \\
\text { dalam penentuan tipologi } \\
\text { desa wisata, didasarkan } \\
\text { pada pendapat pihak ahli }\end{array}$ & $\begin{array}{l}\text { Variabel yang } \\
\text { disepakati sebagai } \\
\text { penentu nilai } \\
\text { tipologi desa wisata } \\
\text { Kabupaten } \\
\text { Ponorogo }\end{array}$ \\
\hline 3 & $\begin{array}{l}\text { Analitycal } \\
\text { Hierarchy } \\
\text { Process } \\
\text { (AHP) }\end{array}$ & $\begin{array}{l}\text { Untuk mengetahui bobot } \\
\text { setiap variabel yang } \\
\text { berpengaruh dalam } \\
\text { penentuan tipologi } \\
\text { pengembangan desa wisata. }\end{array}$ & $\begin{array}{l}\text { Tipologi desa wisata } \\
\text { Kabupaten } \\
\text { Ponorogo } \\
\text { berdasarkan } \\
\text { kesamaan }\end{array}$ \\
\hline 4 & Skoring & $\begin{array}{l}\text { Untuk memberikan } \\
\text { penilaian pada setiap } \\
\text { variabel yang berpengaruh } \\
\text { dalam penentuan tipologi } \\
\text { desa wisata dimasing- } \\
\text { masing desa. }\end{array}$ & $\begin{array}{l}\text { karakteristik } \\
\text { komponen } \\
\text { pembentuk desa } \\
\text { wisatanya. }\end{array}$ \\
\hline 5 & $\begin{array}{c}\text { SWOT } \\
\text { Analysis }\end{array}$ & $\begin{array}{l}\text { Untuk mengetahui } \\
\text { kekuatan, kelemahan, } \\
\text { peluang dan ancaman } \\
\text { pengembangan desa wisata } \\
\text { di Kabupaten Ponorogo }\end{array}$ & $\begin{array}{l}\text { Rekomendasi } \\
\text { pengembangan pada } \\
\text { setiap tipologi desa } \\
\text { wisata di Kabupaten } \\
\text { Ponorogo. }\end{array}$ \\
\hline
\end{tabular}

\section{METODE PENELITIAN}

Penelitian ini menggunakan pendekatan rasionalistik [5] karena didasarkan pada tinjauan teori yang relevan terhadap topik bahasan serta fakta empirik yang ada di lapangan. Dengan jenis penelitian deskriptif eksploraif yang menurut Nazir, [6]; Arikunto, [7] yaitu penelitian dengan menyajikan data deskripsi, gambaran, atau lukisan secara sistematis, faktual dan akurat mengenai fakta-fakta, sifat-sifat serta hubungan antar fenomena dengan menggali secara luas terkait hal-hal yang dapat mempengaruhi atau menjadi sebab dari suatu hal.

Variabel dalam penelitian ini antara lain:

1. Kegiatan berpotensi ekonomi,

2. Kegiatan atau aktivitas pengembangan masyarakat,

3. Kegiatan pariwisata berpengaruh bagi fisik lingkungan,

4. Keragaman jenis daya tarik wisata,

5. Keunikan daya tarik,

6. Penyediaan sarana prasarana pendukung desa wisata,

7. Partisipasi masyarakat setempat,

8. Partisipasi pemerintah desa di kawasan penelitian,

9. Ketersediaan pihak pengelola desa wisata,

10. Jarak tempuh dari ibukota kabupaten,

11. Kemudahan akses jalan menuju lokasi daya tarik, dan

12. Kendaraan yang dapat menjangkau lokasi daya tarik.

Beberapa alat analisis yang digunakan dalam studi ini, dapat dilihat pada Tabel 1.
Tabel 2

Rekapitulasi Data Identifikasi Karakteristik Desa Wisata Kabupaten Ponorogo

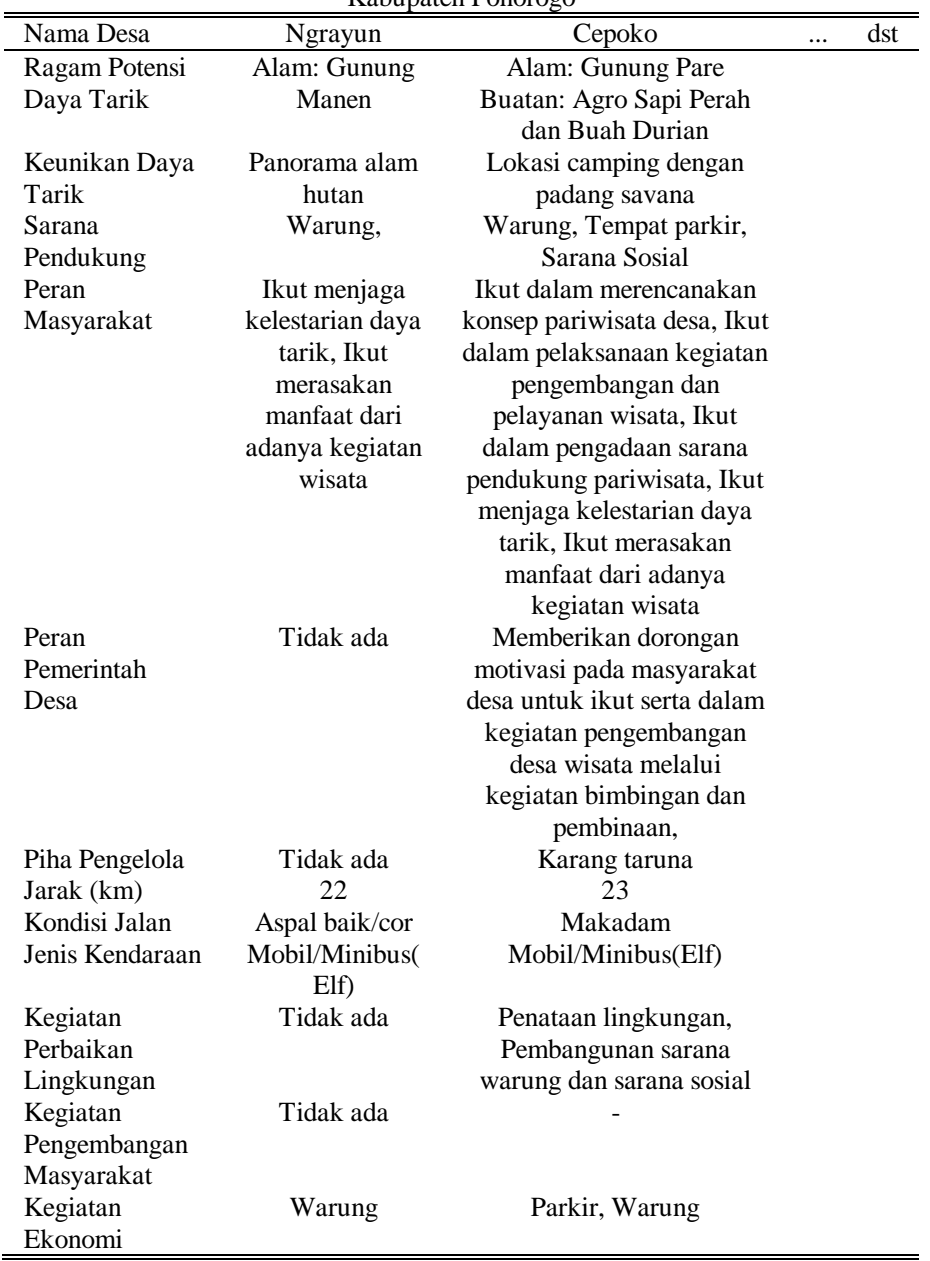

\section{HASIL DAN DISKUSI}

\section{A. Identifikasi Karakteristik Komponen Pembentuk Desa Wisata Kabupaten Ponorogo}

Karena Berdasarkan hasil rekap observasi lapangan di 21 kecamatan Kabupaten Ponorogo didapati kondisi dimana jumlah pengembangan desa wisata tidak lagi tersebar hanya di 70 desa, namun sudah mencapai 84 desa. Sehingga dalam pendiskripsian kondisi variabel di masing-masing desa tidak lagi dilakukan di 70 desa, namun keseluruhan 84 desa, yang dikelompokkan pada lingkup kecamatan.

Tabel 2 merupakan contoh data yang penulis gunakan sebagai pedoman penulisan diskripsi sasaran identifikasi karakteristik komponen pembentuk desa wisata sasaran 1.

\section{B. Analisis Variabel dalam Penentuan Tipologi Desa Wisata Kabupaten Ponorogo}

Dalam menemukan variabel penting tipologi desa wisata Kabupaten Ponorogo dilakukan identifikasi menggunakan Analisis Delphi dengan pakar yang dijadikan responden adalah: 
Pemerintah a. Bappeda Kabupaten Ponorogo

b. Dinas Pariwisata Kabupaten Ponorogo

Masyarakat a. Pokdarwis Kabupaten Ponorogo

b. Tokoh Masyarakat

Akademisi a. Dosen Perguruan Tinggi

Setelah melakukan 2 tahap wawancara dan 1 iterasi diketahui bahwa semua variabel telah mencapai konsensus beserta dengan parameternya. Adapun variabel dan paramater yang telah disepakati untuk dapat digunakan dalam tahap analisis selanjutnya dapat dilihat pada Tabel 3 .

Tabel 3

Variabel AHP dan Parameter Skoring Analysis

\begin{tabular}{|c|c|c|}
\hline Variabel & & Skoring \\
\hline \multirow{5}{*}{$\begin{array}{l}\text { Kegiatan berpotensi } \\
\text { ekonomi }\end{array}$} & 1 & Tidak terdapat kegiatan ekonomi \\
\hline & 2 & Terdapat 1-2 kegiatan ekonomi \\
\hline & 3 & Terdapat 3 kegiatan ekonomi \\
\hline & 4 & Terdapat 4 kegiatan ekonomi \\
\hline & 5 & Terdapat $>4$ kegiatan ekonomi \\
\hline \multirow{5}{*}{$\begin{array}{l}\text { Kegiatan atau } \\
\text { aktivitas } \\
\text { pengembangan } \\
\text { masyarakat }\end{array}$} & 1 & $\begin{array}{l}\text { Tidak terdapat kegiatan pengembangan } \\
\text { masyarakat }\end{array}$ \\
\hline & 2 & $\begin{array}{l}\text { Terdapat } 1-2 \text { kegiatan pengembangan } \\
\text { masyarakat }\end{array}$ \\
\hline & 3 & Terdapat 3 kegiatan pengembangan masyarakat \\
\hline & 4 & Terdapat 4 kegiatan pengembangan masyarakat \\
\hline & 5 & $\begin{array}{l}\text { Terdapat > } 4 \text { kegiatan pengembangan } \\
\text { masyarakat }\end{array}$ \\
\hline \multirow{5}{*}{$\begin{array}{l}\text { Kegiatan pariwisata } \\
\text { berpengaruh bagi } \\
\text { pengembangan fisik } \\
\text { lingkungan }\end{array}$} & 1 & Tidak terdapat kegiatan pro fisik lingkungan \\
\hline & 2 & Terdapat 1-2 kegiatan pro fisik lingkungan \\
\hline & 3 & Terdapat 3 kegiatan pro fisik lingkungan \\
\hline & 4 & Terdapat 4 kegiatan pro fisik lingkungan \\
\hline & 5 & Terdapat > 4 kegiatan pro fisik lingkungan \\
\hline \multirow{5}{*}{$\begin{array}{l}\text { Keragaman jenis } \\
\text { daya tarik wisata }\end{array}$} & 1 & Hanya terdapat 1 jenis daya tarik \\
\hline & 2 & - \\
\hline & 3 & Terdapat 2-3 jenis daya tarik \\
\hline & 4 & - \\
\hline & 5 & Terdapat $\geq 4$ jenis daya tarik \\
\hline \multirow[t]{5}{*}{$\begin{array}{l}\text { Keunikan daya } \\
\text { tarik }\end{array}$} & 1 & $\begin{array}{l}\text { Terdapat > } 3 \text { desa wisata sejenis dalam lingkup } \\
\text { kabupaten }\end{array}$ \\
\hline & 2 & $\begin{array}{l}\text { Terdapat } 3 \text { desa wisata sejenis dalam lingkup } \\
\text { kabupaten }\end{array}$ \\
\hline & 3 & $\begin{array}{l}\text { Terdapat } 2 \text { desa wisata sejenis dalam lingkup } \\
\text { kabupaten }\end{array}$ \\
\hline & 4 & $\begin{array}{l}\text { Terdapat } 1 \text { desa wisata sejenis dalam lingkup } \\
\text { kabupaten }\end{array}$ \\
\hline & 5 & $\begin{array}{l}\text { Tidak trdapat desa wisata sejenis dalam lingkup } \\
\text { kabupaten }\end{array}$ \\
\hline \multirow{6}{*}{$\begin{array}{l}\text { Penyediaan sarana } \\
\text { prasarana } \\
\text { pendukung desa } \\
\text { wisata }\end{array}$} & 1 & Tidak terdapat sarana prasarana \\
\hline & 2 & Terdapat $1-2$ jenis sarana prasarana \\
\hline & 3 & Terdapat 3 jenis sarana prasarana \\
\hline & 4 & Terdapat 4 jenis sarana prasarana \\
\hline & 5 & Terdapat $>4$ jenis sarana prasarana \\
\hline & & $\begin{array}{ll}\ldots \\
\mathrm{dst}\end{array}$ \\
\hline
\end{tabular}

C. Analisis Penentuan Tipologi Desa Wisata Kabupaten

Ponorogo berdasarkan Kesamaan Karakteristik Komponen

Pembentuk Desa Wisatanya

Untuk mendapatkan hasil akhir dari analisis penentuan tipologi desa wisata dilakukan 2 tahap analisis terlebih dahulu dengan metode analisis AHP dan Skoring.

1) Analisis Penentuan Bobot tiap Variabel yang digunakan dalam Penentuan Tipologi Desa Wisata Kabupaten Ponorogo

Penggunaan metode AHP akan menghasilkan nilai bobot dari setiap variabel yang digunakan dalam
Tabel 4

Skor dan Kondisi Variabel Desa Wisata Kabupaten Ponorogo

\begin{tabular}{|c|c|c|c|}
\hline Kecamatan & Desa & Skor & Keterangan \\
\hline \multicolumn{4}{|c|}{ Variabel : Kegiatan berpotensi ekonomi } \\
\hline \multirow[t]{11}{*}{ Ngrayun } & Ngrayun & 2 & $\begin{array}{l}\text { Kegiatan ekonomi yang } \\
\text { berkembang adalah Warung }\end{array}$ \\
\hline & Cepoko & 2 & $\begin{array}{l}\text { Kegiatan ekonomi yang } \\
\text { berkembang adalah Parkir, } \\
\text { Warung }\end{array}$ \\
\hline & $\begin{array}{l}\text { Baosan } \\
\text { Lor }\end{array}$ & 3 & $\begin{array}{l}\text { Kegiatan ekonomi yang } \\
\text { berkembang adalah Parkir, } \\
\text { Warung, Pemandu }\end{array}$ \\
\hline & Selur & 4 & $\begin{array}{l}\text { Kegiatan ekonomi yang } \\
\text { berkembang adalah Parkir, } \\
\text { Produk Sari Janggel, } \\
\text { Warung, Pemandu }\end{array}$ \\
\hline & Gedangan & 1 & $\begin{array}{l}\text { Tidak ada kegiatan ekonomi } \\
\text { yang berkembang }\end{array}$ \\
\hline & Temon & 2 & $\begin{array}{l}\text { Kegiatan ekonomi yang } \\
\text { berkembang adalah Produk } \\
\text { lokal Kopi Klobot, Warung }\end{array}$ \\
\hline & Mrayan & 2 & $\begin{array}{l}\text { Kegiatan ekonomi yang } \\
\text { berkembang adalah Produk } \\
\text { lokal Kerajinan Batu Akik, } \\
\text { Warung }\end{array}$ \\
\hline & $\begin{array}{l}\text { Baosan } \\
\text { Kidul }\end{array}$ & 2 & $\begin{array}{l}\text { Kegiatan ekonomi yang } \\
\text { berkembang adalah Produk } \\
\text { lokal Telur Bakar, Warung }\end{array}$ \\
\hline & Wonodadi & 1 & $\begin{array}{l}\text { Tidak ada kegiatan ekonomi } \\
\text { yang berkembang }\end{array}$ \\
\hline & Binade & & $\begin{array}{l}\text { Tidak ada kegiatan ekonomi } \\
\text { yang berkembang }\end{array}$ \\
\hline & & $\begin{array}{ll}\cdots \\
\mathrm{dst}\end{array}$ & \\
\hline
\end{tabular}

penelitian. Dengan nilai incosistecy sebesar 0,06 yang artinya tingkat kesalahan rendah, dapat diketahui bahwa variabel yang memiliki bobot pengaruh tertinggi dalam penentuan tipologi desa wisata di Kabupaten Ponorogo adalah keunikan daya tarik. Kemudian dilanjutkan di posisi kedua variabel partisipasi masyarakat dan baru variabel lainnya. Secara berurutan variabel dengan bobot tertinggi hingga terendah adalah sebagai berikut:

1. Keunikan daya tarik $(0,339)$

2. Partisipasi masyarakat setempat $(0,162)$,

3. Keragaman jenis daya tarik wisata $(0,139)$,

4. Penyediaan sarana prasarana pendukung wisata $(0,123)$,

5. Kemudahan akses jalan $(0,074)$,

6. Ketersediaan pihak pengelola $(0,070)$,

7. Kegiatan pengembangan masyarakat $(0,030)$,

8. Partisipasi pemerintah desa $(0,021)$,

9. Kendaraan yang dapat menjangkau lokasi wisata $(0,015)$,

10. Kegiatan pariwisata berpengaruh bagi lingkungan $(0,013)$,

11. Jarak tempuh dari ibukota kabupaten $(0,011)$, dan

12. Kegiatan berpotensi ekonomi $(0,003)$.

2) Pemberian Nilai/Skor tiap Variabel yang digunakan dalam Penentuan Tipologi Desa Wisata Kabupaten Ponorogo

Metode Skoring digunakan dalam pemberian nilai 
skor setiap variabel pada penelitian, dengan memperhatikan data karakteristik setiap variabel di desa wisata pada sasaran 1 dan tolak ukur kriteria yang telah disepakati pada sasaran 2. Artinya, dalam pemberian skor di setiap variabel akan melihat kondisi eksisting di lapangan dan parameter yang sudah disepakati sebelumnya. Adapun contoh Tabel penjelasan skor dan kondisi pada setiap variabel di setiap desa wisata yang ada di Kabupaten Ponorogo adalah pada Tabel 4.

Untuk mendapatkan pembagian tipologi desa wisata Kabupaten Ponorogo berdasarkan kesamaan karakteristik komponen pembentuk desa wisatanya, hasil dari skoring setiap variabel akan dikalikan dengan bobot dari masingmasing variabel AHP dan kemudian diakumulasikan dengan cara menjumlahkan keseluruhan nilai pada setiap variabel untuk masing-masing desa wisata. Hasil skor akhir yang digunakan dalam pembagian kelompok tipologi desa wisata adalah hasil penjumlahan dari pengkalian data skoring dengan bobot nilai setiap variabel hasil AHP. Dimana nilai maksimal yang mungkin dihasilkan adalah 5 dan nilai minimalnya adalah 1 . Sehingga apabila dalam penelitian ini dicari 3 tipologi desa wisata, pembagian interval dan kelompok tipologi yang digunakan dalam penelitian adalah sebagai berikut.

$$
\begin{aligned}
\text { Interval }= & \frac{\text { total nilai maksimal }- \text { total nilai minimal }}{3} \\
& =\frac{5-1}{3}=1,333
\end{aligned}
$$

Sehingga pembagian interval kelompok tipologi desa

\begin{tabular}{|c|c|c|c|}
\hline & Pengelomp & n Tipologi De & ata Kabupaten Ponorogo \\
\hline No & Tipologi & $\begin{array}{l}\text { Interval } \\
\text { Skoring }\end{array}$ & Keterangan \\
\hline 1. & Tipologi I & $>3.667$ & $\begin{array}{l}\text { Berpotensi tinggi sebagai lokasi } \\
\text { pengembangan Desa Wisata }\end{array}$ \\
\hline 2. & Tipologi II & $2,334-3,667$ & $\begin{array}{l}\text { Berpotensi sedang sebagai lokasi } \\
\text { pengembangan Desa Wisata }\end{array}$ \\
\hline 3. & Tipologi III & $1-2,333$ & $\begin{array}{l}\text { Berpotensi rendah sebagai lokasi } \\
\text { pengembangan Desa Wisata }\end{array}$ \\
\hline
\end{tabular}
wisata yang terbentuk ditunjukkan dengan Tabel 5.

Setelah nilai masing-masing variabel di setiap desa dikalikan dengan botot AHP dan jumlahkan, didapatkan hasil akhir skoring dan pembagian tipologi desa wisata Kabupaten Ponorogo dapat dilihat pada Tabel 6 dan 7.

Tabel 6

Nilai Total Hasil Skoring dan Pembagian Tipologi Desa Wisata Kabupaten Ponorogo

\begin{tabular}{|c|c|c|c|}
\hline & Sendang & 2,502 & Cukup Berpotensi \\
\hline \multirow[t]{3}{*}{ Slahung } & Wates & 2,351 & Cukup Berpotensi \\
\hline & Caluk & 3,543 & Cukup Berpotensi \\
\hline & Slahung & 1,955 & Kurang Berpotensi \\
\hline \multirow[t]{3}{*}{ Bungkal } & Kupuk & 4,324 & Berpotensi Tinggi \\
\hline & Pager & 4,258 & Berpotensi Tinggi \\
\hline & Munggu & 1,698 & Kurang Berpotensi \\
\hline \multirow[t]{3}{*}{ Sambit } & Bedingin & 4,281 & Berpotensi Tinggi \\
\hline & Ringinanom & 2,479 & Cukup Berpotensi \\
\hline & Gajah & 2,695 & Cukup Berpotensi \\
\hline \multirow[t]{6}{*}{ Sawoo } & Grogol & 3,287 & Cukup Berpotensi \\
\hline & Temon & 3,245 & Cukup Berpotensi \\
\hline & Pangkal & 2,079 & Kurang Berpotensi \\
\hline & Tumpakpelem & 1,865 & Kurang Berpotensi \\
\hline & Ngindeng & 3,658 & Cukup Berpotensi \\
\hline & Sawoo & 1,934 & Kurang Berpotensi \\
\hline \multirow[t]{2}{*}{ Sooko } & Ngadirojo & 1,717 & Kurang Berpotensi \\
\hline & Jurug & 2,386 & Cukup Berpotensi \\
\hline \multirow[t]{3}{*}{ Pudak } & Krisik & 3,749 & Berpotensi Tinggi \\
\hline & Pudak Wetan & 3,48 & Cukup Berpotensi \\
\hline & Pudak Kulon & 1,764 & Kurang Berpotensi \\
\hline \multirow[t]{5}{*}{ Pulung } & Kesugihan & 3,836 & Berpotensi Tinggi \\
\hline & Munggung & 1,977 & Kurang Berpotensi \\
\hline & Wagir Kidul & 4,241 & Berpotensi Tinggi \\
\hline & Banaran & 1,706 & Kurang Berpotensi \\
\hline & Pulung Merdeka & 1,913 & Kurang Berpotensi \\
\hline \multirow[t]{4}{*}{ Mlarak } & Jabung & 3,044 & Cukup Berpotensi \\
\hline & Kaponan & 1,778 & Kurang Berpotensi \\
\hline & Gontor & 3,26 & Cukup Berpotensi \\
\hline & Suren & 3,049 & Cukup Berpotensi \\
\hline \multirow[t]{2}{*}{ Siman } & Manuk & 2,807 & Cukup Berpotensi \\
\hline & Ronosentanan & 1,31 & Kurang Berpotensi \\
\hline \multirow[t]{3}{*}{ Jetis } & Tegalsari & 2,606 & Cukup Berpotensi \\
\hline & Josari & 3,712 & Berpotensi Tinggi \\
\hline & Keradenan & 2,248 & Kurang Berpotensi \\
\hline Balong & Tatung & 3,445 & Cukup Berpotensi \\
\hline & Ngumpul & 2,456 & Cukup Berpotensi \\
\hline & Ngendut & 3,068 & Cukup Berpotensi \\
\hline & Karang Patihan & 3,246 & Cukup Berpotensi \\
\hline & Pandak & 3,775 & Berpotensi Tinggi \\
\hline & Bulak & 3,82 & Berpotensi Tinggi \\
\hline Kauman & Nglarangan & 1,454 & Kurang Berpotensi \\
\hline & Sumoroto & 3,551 & Cukup Berpotensi \\
\hline Jambon & Srandil & 2,223 & Kurang Berpotensi \\
\hline & Jonggol & 3,897 & Berpotensi Tinggi \\
\hline & Sidoharjo & 2,172 & Kurang Berpotensi \\
\hline & Bulu Lor & 2,316 & Kurang Berpotensi \\
\hline Badegan & Biting & 3,287 & Cukup Berpotensi \\
\hline & Dayakan & 1,603 & Kurang Berpotensi \\
\hline Sampung & Sampung & 1,996 & Kurang Berpotensi \\
\hline & Kunthi & 1,878 & Kurang Berpotensi \\
\hline & Jenangan & 3,223 & Cukup Berpotensi \\
\hline & Pagerukir & 4,242 & Berpotensi Tinggi \\
\hline & Nglurup & 2,852 & Cukup Berpotensi \\
\hline & Glinggang & 4,086 & Berpotensi Tinggi \\
\hline & Gelang Kulon & 2,572 & Cukup Berpotensi \\
\hline & Puhijo & 2,602 & Cukup Berpotensi \\
\hline Sukorejo & Golan & 1,956 & Kurang Berpotensi \\
\hline & Sukorejo & 1,833 & Kurang Berpotensi \\
\hline & Kedung Banteng & 2,767 & Cukup Berpotensi \\
\hline Ponorogo & Seluruh kelurahan & 3,859 & Berpotensi Tinggi \\
\hline Babadan & Patihan Wetan & 3,896 & Berpotensi Tinggi \\
\hline & Kadipaten & 2,139 & Kurang Berpotensi \\
\hline & Sukosari & 2,262 & Kurang Berpotensi \\
\hline & Babadan & 2,253 & Kurang Berpotensi \\
\hline Jenangan & Setono & 2,848 & Cukup Berpotensi \\
\hline & Paringan & 3,799 & Berpotensi Tinggi \\
\hline Ngebel & Ngrogung & 3,339 & Cukup Berpotensi \\
\hline & Sahang & 3,039 & Cukup Berpotensi \\
\hline & Wagir Lor & 4,064 & Berpotensi Tinggi \\
\hline & Ngebel & 3,989 & Berpotensi Tinggi \\
\hline & Talun & 2,617 & Cukup Berpotensi \\
\hline & Gondowido & 3,992 & Berpotensi Tinggi \\
\hline & Pupus & 3,754 & Berpotensi Tinggi \\
\hline
\end{tabular}

\begin{tabular}{llcl}
\hline \hline Kecamatan & Desa/ Kelurahan & Total Skor & Kategori Tipologi \\
\hline Ngrayun & Ngrayun & 2,642 & Cukup Berpotensi \\
& Cepoko & 3,82 & Berpotensi Tinggi \\
& Baosan Lor & 3,95 & Berpotensi Tinggi \\
& Selur & 4,436 & Berpotensi Tinggi \\
& Gedangan & 2,534 & Cukup Berpotensi \\
& Temon & 4,129 & Berpotensi Tinggi \\
& Mrayan & 4,052 & Berpotensi Tinggi \\
& Baosan Kidul & 2,308 & Kurang Berpotensi \\
& Wonodadi & 1,34 & Kurang Berpotensi \\
& Binade & 2,502 & Cukup Berpotensi
\end{tabular}


Tabel 7

Hasil Rekapitulasi Skor Desa Wisata Kabupaten Ponorogo

\begin{tabular}{cll}
\hline \hline Tipologi & \multicolumn{1}{c}{ Kategori } & \multicolumn{1}{c}{ Jumlah Desa } \\
\hline Tipologi I & Berpotensi tinggi sebagai lokasi & 24 Desa tersebar di 13 \\
& pengembangan Desa Wisata & Kecamatan \\
Tipologi II & $\begin{array}{l}\text { Berpotensi sedang sebagai lokasi } \\
\text { pengembangan Desa Wisata }\end{array}$ & 33 Desa tersebar di 16 \\
& Kecamatan \\
Tipologi III & $\begin{array}{l}\text { Berpotensi rendah sebagai lokasi } \\
\text { pengembangan Desa Wisata }\end{array}$ & 27 Desa tersebar di 16 \\
& Kecamatan \\
\hline \hline
\end{tabular}

Berdasarkan hasil Tabel 7, dapat diketahui bahwa desa wisata Kabupaten Ponorogo telah terbagi dalam 3 kategori sebagai berikut.

a. Tipologi I

Dasa tipologi I adalah desa dengan potensi tinggi untuk dikembangkan sebagai desa wisata di Kabupaten Ponorogo. Terdapat 24 desa yang termasuk dalam tipologi I dan lokasinya tersebar di 13 kecamatan yang berbeda. Dari hasil analisis, adapun desa tipologi I diketahui memiliki dominasi nilai rata-rata komponen/variabel pembentuk desa wisata yang tergolong tinggi, tepatnya 5 variabel tinggi, 4 variabel cukup dan 3 variabel lainnya rendah. Melihat tingginya nilai-nilai tersebut, terutama untuk variabel penyediaan sarana pendukung, dapat dijadikan indikator bagi pemerintah untuk tidak menyalurkan bantuan pembiayaan bagi desa tipologi I, dikarenakan sasaran utama bantuan pembiayaan yang sesungguhnya adalah desa wisata yang berpotensi namun belum memiliki sarana pendukung yang memadai.

b. Tipologi II

Seperti yang dijelaskan sebelumnya, dasa pada tipologi II adalah desa dengan potensi sedang atau cukup untuk dikembangkan sebagai desa wisata di Kabupaten Ponorogo. Terdapat 33 desa yang termasuk dalam tipologi II dan tersebar di 16 kecamatan yang berbeda. Dari hasil analisis, adapun desa pada tipologi II ini diketahui memiliki dominasi nilai rata-rata komponen/variabel pembentuk desa wisata yang tergolong cukup, tepatnya 1 variabel tinggi, 7 variabel cukup dan 4 variabel lainnya rendah. Dengan nilai potensi yang cukup dan variabel penyediaan sarana pendukung yang tergolong sedang/kurang, dapat dijadikan indikator bagi pemerintah untuk segera menyalurkan bantuan pembiayaan bagi desa tipologi II, dikarenakan desa tipologi II memiliki karakteristik yang sesuai dengan yang diharapkan pemerintah untuk menerima bantuan dana yaitu desa wisata yang berpotensi namun belum memiliki sarana pendukung yang memadai.

\section{c. Tipologi III}

Dasa tipologi III adalah desa dengan potensi rendah untuk dikembangkan sebagai desa wisata di Kabupaten Ponorogo. Tetapnya berada di 27 desa yang tersebar di 16 kecamatan yang berbeda di Kabupaten Ponorogo. Dari hasil analisis, adapun desa tipologi III diketahui memiliki dominasi nilai rata-rata komponen/variabel pembentuk desa wisata yang tergolong rendah, tepatnya 1 variabel tinggi, 2 variabel cukup dan 8 variabel lainnya rendah. Dengan nilai potensinya yang masih rendah ini, dapat dijadikan indikator bagi pemerintah untuk tidak menyalurkan bantuan pembiayaan bagi desa tipologi III. Hal lain mungkin akan terjadi, jika desa tipologi III berubah dan dapat naik ke tipologi II atau tipologi I.

\section{KESIMPULAN}

Pada penelitian yang bertujuan untuk mengetahui kondisi pengembangan desa wisata di Kabupaten Ponorogo, hingga kemudian dirumuskan rekomendasi pengembangan desa wisata yang tepat bagi desa-desa wisata Kabupaten Ponorogo kedepannya. Berikut ini merupakan hasil simpulan yang diperoleh dari penelitian ini :

1. Untuk daerah yang pariwisatanya terbilang kurang terkenal, hanya Reog, Kabupaten Ponorogo dinilai cukup berani dalam mengembangkan konsep desa wisata. Dari hasil identifikasi yang dilakukan, sampai dengan awal 2018, sudah ada 84 desa di Kabupaten Ponorogo yang diupayakan untuk menjadi desa wisata meski belum semuanya berhasil.

2. Desa wisata Kabupaten Ponorogo memiliki kecenderungan untuk mengembangkan potensi alam sebagai daya tarik wisata. Dari data identifikasi dapat diketahui bahwa, dari 84 desa di Kabupaten Ponorogo yang mengembangkan desa wisata, 52 desa atau $61.9 \%$ diantaranya menjadikan alam sebagai daya tarik desanya. Hanya ada masing-masing 3 desa atau $3.57 \%$ yang mengembangkan wisata seni/budaya dan wisata kuliner; 8 desa atau $9.52 \%$ yang mengembangkan wisata buatan/agro dan 18 desa atau $21.43 \%$ sisanya yang mengembangkan wisata sejarah/religi.

3. Jika dilihat lebih dalam, dari karakteristik komponen pembentuk desa wisatanya, masing-masing desa wisata di Kabupaten Ponorogo dapat dikelompokkan menjadi 3 tipologi. Kelompok tipologi I yaitu desa yang berpotensi tinggi untuk dikembangkan sebagai desa wisata, berjumlah 24 desa dan tersebar di 13 kecamatan yang berbeda. Berikutnya tipologi II, desa dengan potensi sedang atau cukup untuk dapat dikembangkan menjadi desa wisata, berjumlah 33 desa dan tersebar di 16 kecamatan yang berbeda. Terakhir, kelompok tipologi III adalah desa dengan potensi rendah untuk dikembangkan menjadi desa wisata, berjumlah 27 desa yang tersebar di 16 kecamatan yang berbeda. Dari ketiga tipologi, yang direkomendasikan dapat menerima bantuan pembiayaan dari Pemerintah Kabupaten Ponorogo sejumlah 25 juta adalah desa wisata pada tipologi II. Hal ini dikarenakan desa tipologi II memiliki karakteristik yang sesuai dengan yang diharapkan pemerintah untuk menerima bantuan dana yaitu desa wisata yang berpotensi namun belum memiliki sarana pendukung yang memadai.

\section{DAFTAR PUSTAKA}


Melalui Konsep Community Based Tourism," in Prosiding KS: Riset \& PKM, 2015, pp. $301-444$.

[2] G. Prafitri and M. Damayanti, "Kapasitas Kelembagaan Dalam Pengembangan Desa Wisata (Studi Kasus: Desa Wisata Ketenger, Banyumas)," J. Pengemb. Kota, vol. 4, no. 1, pp. 76-86, 2016.

[3] Bappeda Ponorogo, "Berita Musrenbang RPJMD Kabupaten Ponorogo Tahun 2016-2021," Bappeda Ponorogo, 2016. [Online]. Available: http://bappeda.ponorogo.go.id/index.php/beerita/bappeda/item/197musrenbang-rpjmd-kabupaten-ponorogo-tahun-2016-2021 .

[4] Bappeda Ponorogo, "Surat Keputusan Bupati Nomor 188.45/1769/405.29/2017 tentang Penetapan Desa Wisata," 2017.

[5] N. Muhadjir, Metode Penelitian Kualitatif. Jakarta, 2000.

[6] M. Nazir, Metode Penelitian. Jakarta: Ghalia Indonesia, 1998.

[7] Arikunto, Prosedur Suatu Penelitian: Pendekatan Praktek. Jakarta: Rineka Cipta, 2002. 